\title{
Effect of size grading on the growth of pirarucu Arapaima gigas reared in earthen ponds
}

\author{
Adriana Ferreira Lima ${ }^{1}$ \\ ${ }^{1}$ Empresa Brasileira de Pesquisa Agropecuária, Embrapa Pesca e Aquicultura \\ Palmas, Tocantins, Brazil \\ Corresponding author: Adriana Ferreira Lima (adriana.lima@embrapa.br)
}

\begin{abstract}
Size grading is a common management practice in fish farming to minimize growth variability. Such practice has not been established for pirarucu Arapaima gigas. Therefore, the present study assessed the effect of size grading on the growth of pirarucu. Juvenile pirarucu were divided into three groups: ungraded fish (U: mean initial weight $1.12 \mathrm{~kg}$ ), small fish (S: mean initial weight $0.81 \mathrm{~kg}$ ), and large fish (L: mean initial weight $1.36 \mathrm{~kg}$ ), and reared for 129 days (phase I) and 158 additional days (phase II), consecutively. No significant difference was observed in the final length, specific growth rate, biomass, survival and feed conversion rate between fish groups. Ungraded fish presented a greater decrease in the coefficient of variation for weight in phase I than in phase II. Size sorting resulted in significantly higher growth after 287 days of farming in the L-graded fish $(9.49 \mathrm{~kg}$, final weight), followed by the ungraded group $(8.80 \mathrm{~kg})$ and $\mathrm{S}$-graded group $(8.01 \mathrm{~kg})$. However, the mean weight of pooled S- and L-graded fish was similar to the ungraded fish group in phase I and phase II, indicating that grading did not improve the general performance of pirarucu in captivity.
\end{abstract}

Keywords: Arapaima gigas; growth; production; management; size sorting; size variation

\section{INTRODUCTION}

The aquaculture of pirarucu Arapaima gigas (Schinz, 1822) has drawn considerable interest in Brazil and has resulted in increased growth production in the last decade (IBAMA, 2005; IBGE, 2016). Some of the characteristics that encourage the productive sector to invest in the aquaculture of the species are fast growth (up to $10 \mathrm{~kg}$ in one year), aerial breathing, and tolerance to high levels of ammonia concentration in the water and white boneless mild-flavor meat (Bard \& Imbiriba, 1986; Saint-Paul, 1986; Imbiriba, 2001; Cavero et al., 2004; Fogaça et al., 2011). Considering that pirarucu has been historically subjected to high fishing effort, and now it is classified as a vulnerable species and listed as a threatened species by the Convention on International Trade in Endangered Species of Wild Fauna and Flora; aquaculture is an alternative to provide this fish to the market without threatening natural populations, also reducing pressure on the wild stock.
Intensification of pirarucu farming requires management practices to optimize production. Currently, pirarucu is farmed in earthen ponds, in a two-phase system, as $10 \mathrm{~g}$ juveniles are reared up to $1 \mathrm{~kg}$ and resorted and reared up to the market size of $10-15 \mathrm{~kg}$ (Rebelatto-Junior et al., 2015). Fish reared during long periods and without any management practices to maintain group homogeneity may result in social hierarchy due to differences in weight/length, and sometimes followed by aggressiveness among individuals (Koebele, 1985; Jensen, 1990; Martins et al., 2005). Differences in growth rate are described for several fish species and may be caused by competition for food or other behavioral factors that inhibit growth (Volpato \& Fernandes, 1994; Szczepkowski et al., 2011).

Heterogeneous growth and aggressiveness among individuals have been reported for juvenile pirarucu during weaning (Cavero et al., 2003a), and for juveniles $(10 \mathrm{~g})$ reared in cages at different stocking densities

Corresponding editor: Alvaro Bicudo 
(Cavero et al., 2003b). Sorting fish by size (or grading) is a common practice to minimize growth variation along the production cycle of several species (Jensen, 1990; Martins et al., 2005; Onders et al., 2011). One of the positive effects of such practice is better weight gain, as the dominance of large fish over small ones is suppressed when fish are sorted at regular intervals (Baardvik \& Jobling, 1990). However, no study is available on the effect of sorting in the production of pirarucu. In this way, the objective of the present study was to assess the effect of size grading of pirarucu reared in earthen ponds upon production efficiency.

\section{MATERIALS AND METHODS}

\section{Fish stocking and rearing conditions}

The study was conducted at Baixão Verde Farm, in the city of Almas, and Serra Azul Farm, in the city of Palmas, both in the state of Tocantins, Brazil, between October 2014 and August 2015. The study complied with the Brazilian guidelines for the care and use of animals for scientific and educational purposes (03/2015). Fish $(13.4 \pm 2.31 \mathrm{~cm}$ and $21.22 \pm 9.87 \mathrm{~g})$ were purchased from a commercial farm and stocked in earthen ponds until they reached mean weight \pm standard deviation (SD) of $1.1 \pm 0.3 \mathrm{~kg}$ to the commencement of the experiment. Fish were fed daily a commercial fish feed for carnivorous species (extruded, $40 \%$ crude protein) until apparent satiation.

Before the experiment, earthen ponds of $1,000 \mathrm{~m}^{2} \times$ $1.5 \mathrm{~m}$ depth were wholly drained and sun-dried for seven days and then limed $\left(100 \mathrm{~g} \mathrm{CaCO}_{3} \mathrm{~m}^{-2}\right)$ and fertilized ( $3 \mathrm{~g}^{2}$ urea $\mathrm{m}^{-2}$ and $10 \mathrm{~g}$ rice bran $\left.\mathrm{m}^{-2}\right)$ (Lima et al., 2015). Next, ponds were filled with water and fish stocked.

\section{Experimental design}

Fish were divided into three groups: (U) ungraded fish (control), (S) small fish and (L) large fish, in duplicate (one replicate per farm), totaling six experimental units (Wallat et al., 2005) stocked at density of 1,000 fish $\mathrm{ha}^{-1}$ (100 fishes per pond), suitable for commercial production (Ono \& Kedhi, 2013). The study was divided into phase I (129 days), when fish were randomly assigned to the ungraded group $(1.12 \pm 0.05$ $\mathrm{kg})$, and sorted by hand to the $\mathrm{S}-(0.81 \pm 0.01 \mathrm{~kg})$ and $\mathrm{L}-(1.36 \pm 0.33 \mathrm{~kg})$ graded groups with weight below and above the mean weight of the unsorted group, respectively (Wallace \& Kolbeinshavn, 1988); and phase II (158 days), when only S- and L-graded fish groups were graded again. In this way, fish were reared for a total of 287 days, which added to 90 days in the nursery phase, reached the recommendation of one year farming in captivity (Imbiriba, 2001).

\section{Feeding}

During the experiment, fish were fed twice daily (07:00 and 17:00 h), a commercial extruded feed for carnivorous species ( $40 \%$ crude protein). Feed portions were thoroughly distributed on the water surface in each pond. In the first 45 days, fish were fed at a rate of $3 \%$ biomass $\mathrm{d}^{-1}$, then $2.5 \%$ biomass $\mathrm{d}^{-1}$ until the end of phase I (129 days total). During phase II, fish were fed at a rate of $1.8 \%$ biomass $\mathrm{d}^{-1}$. All fish were individually measured and weighed at the beginning and end of the experiment. Intermediate measurements were taken at days 40, 80,129, 177 and 234, when 30 fish per pond were randomly captured with a dragnet, and individually measured and weighed.

\section{Hierarchy assessment}

Twenty fish per experimental unit was marked by PIT (passive integrated transponder) tags at the beginning of the experiment to assess the hierarchical fish position during the study period. For each morphometric measurement, fish were classified as subordinate or dominant when lower or higher in weight, respectively, than the mean weight of the group (Cutts et al., 1998; Martins et al., 2005). During the study period, fish were rated as remaining in the position (same), became dominant (up), became subordinate (down) and varied between the dominant and the subordinate groups (varied).

\section{Growth and water quality parameters}

Fish growth performance was assessed based on mean final weight, final biomass, apparent feed conversion ratio $(\mathrm{FCR}=$ total feed intake/total weight gain), coefficient of variation for weight and length $(\mathrm{CV}=$ standard deviation/mean weight or length $\times 100$ ), specific growth rate $(S G R=100 \times(\ln$ final weight $-\ln$ initial weight)/days) and survival $(100 \times$ (final number of fish/initial number of fish)). For each experimental unit, weight and length data were regressed ( $\mathrm{W}=a \mathrm{~L}^{b}$, where $\mathrm{W}$ is weight, $\mathrm{L}$ is the length, $a$ is the constant, and $b$ is the regression exponent). The regression exponent values were compared between experimental units for significant differences (Le Cren, 1951). The fish condition factor $(\mathrm{K})$ was calculated based on the exponential regression index $\left(\mathrm{K}=\mathrm{W} / a \mathrm{~L}^{b}\right)$ (Le Cren, 1951). To assess water quality parameters, temperature and transparency were measured every two days with a thermometer and a Secchi disc, respectively; water $\mathrm{pH}$, ammonia and alkalinity were measured monthly with a commercial colorimetric kit (Alfakit ${ }^{\circledR}$, Florianópolis, SC, Brazil).

\section{Statistical analysis}

For statistical analysis of each variable, the means of each pond was considered the experimental unit, and 
each propriety was considered a block. Data were submitted to analysis of variance and Tukey test $(P<$ 0.05 ). When premises of normality (Shapiro-Wilk) and homogeneity (Bartlett) were not met, data were transformed (Box \& Cox, 1964) or compared by the non-parametric test of Kruskal-Wallis. Values are expressed as mean \pm standard deviation. Statistical analysis was performed in R (R Core Team, 2016).

\section{RESULTS}

\section{Fish growth performance}

Growth performance (weight, length, biomass, SGR, survival and FCR) of pirarucu Arapaima gigas reared in earthen ponds and submitted to different size grading practices are presented in Table 1 . The mean pooled weight of small and large fish $(1.09 \mathrm{~kg})$ at the beginning of the experiment did not differ $(P=0.384)$ from the ungraded fish mean weight $(1.12 \mathrm{~kg})$, considering that fish graded as small or large derived from the ungraded fish group. The mean pooled weight of small and largegraded fish $(4.38 \mathrm{~kg})$ did not differ $(P=0.223)$ from the ungraded group $(4.35 \mathrm{~kg})$ by the end of either phase I or phase II ( $8.75 v s .8 .80 \mathrm{~kg}$, respectively) $(P=0.476)$. Fish size grading only resulted in better performance after 287 days of culture with higher final weight for Lgraded fish, followed by ungraded fish, whereas Sgraded fish presented the lowest final weight. Despite the significant difference in the final weight of fish by the end of phase II, the final weight of the ungraded group did not differ from the pooled mean final weight of the S- and L-graded groups, which indicates that this practice did not improve pirarucu growth performance in captivity.

In phase I, fish SGR did not differ between groups, and it was $21 \%$ higher in the S-graded fish than the other groups. In phase II, no significant differences were observed, but the SGR was higher in L-graded fish and lowered in the S-graded fish group. From phase I to phase II, the SGR was significantly reduced only for the $\mathrm{S}$-graded group $(P=0.0389)$. FCR and survival were similar in all groups.

\section{Growth curve and condition factor}

The confidence interval of the fish growth curves in the different treatments overlapped during most of the study period, only separating towards the end (Fig. 1a) with a significant difference in the final fish weight.

Fish weight and length were adjusted in a curve for each treatment, and the exponential index ( $a$ and $b$ ) of the equations were compared (Table 1). Since no significant difference was observed, a single exponential curve was adjusted with all data on weight and length, resulting in the equation $\mathrm{Y}=0.0027 \mathrm{X}^{3.2656}$, where $\mathrm{Y}$ is weight and $\mathrm{X}$ is the length $(P<0.05)$, and $\mathrm{R}^{2}=98.2 \%$ (Fig. 1b). The curve exponent indicated allometric growth for pirarucu, i.e., higher increment in weight than in length when reared in earthen pond. The condition factors for the fish in the three groups, calculated from the regression indexes, were not significantly different (Fig. 2).

\section{Heterogeneous growth}

The coefficient of variation (CV) used to evaluate growth heterogeneity in each group was high at the beginning of the experiment and tended to decrease in all treatments in both culture phases, but with sharper descent in phase I (Fig. 3). No significant difference was observed for the $\mathrm{CV}$ between groups $(P=0.446)$ or between the initial and final values in phase I or phase II $(P>0.05)$, except for the lower CV of the Lgraded fish weight at the end of phase II $(P=0.048)$. In general, ungraded fish presented a sharper reduction in the CV of weight in phase I, approaching values of S and L-graded fish, demonstrating the natural trend in pirarucu to reduce $\mathrm{CV}$. As for length, in phase I, CV for ungraded fish did not vary, whereas it was reduced for S- and L-graded fish. In phase II, a less pronounced and similar reduction in weight and length $\mathrm{CV}$ between groups was observed. A higher weight variability trend was observed in the initial phases of pirarucu farming.

\section{Hierarchy}

In the ungraded fish group, more individuals remained in the same hierarchical position as at the beginning of the experiment, demonstrating low variation in the social rank established. On the other hand, among the L-graded fish, 50\% remained in the same position, whereas $16.7 \%$ increased their social status. Among the S-graded fish group, $27.2 \%$ increased their social status, whereas $20.8 \%$ varied their hierarchical position more than once during the study. A similar proportion of fish decreased their hierarchical position in all the treatments (Fig. 4).

\section{Water quality}

No significant differences were observed for any of the water quality parameters (Table 2), demonstrating that size grading, and even grouping fish of different mean weight in different ponds did not affect water quality.

\section{DISCUSSION}

Water quality parameters were within recommended values for tropical fish species (Boyd \& Lichtkoppler, 1979) and considered adequate for the farming of pirarucu Arapaima gigas in captivity (Ono \& Kedhi, 2013). As previously reported for yellow perch Perca 
Table 1. Growth performance (initial and final weight and length, biomass, specific growth rate (SGR), survival and feed conversion ratio) of pirarucu Arapaima gigas reared in earthen ponds for 287 days and size graded. Mean values followed by different letters in the same row are significantly different (Tukey test, $P<0.05$ ). SGR is the specific growth rate; $\mathrm{b}$ is the exponent of the exponential regression, analyzed by Kruskal Wallis. *The value of each variable is a mean of all fish in the experimental units of each treatment.

\begin{tabular}{|c|c|c|c|c|c|}
\hline \multirow{3}{*}{ Parameter } & \multicolumn{3}{|c|}{ Size grading } & \multirow{2}{*}{$\begin{array}{c}P \text {-value } \\
\text { (Treatment) }\end{array}$} & \multirow{2}{*}{$\begin{array}{l}P \text {-value } \\
\text { (Block) }\end{array}$} \\
\hline & Ungraded & S-graded & L-graded & & \\
\hline & \multicolumn{5}{|c|}{ Phase I - 0 to 129 days } \\
\hline Initial weight* (kg) & $1.12 \pm 0.05$ & $0.81 \pm 0.01$ & $1.36 \pm 0.33$ & 0.16146 & 0.32635 \\
\hline Final weight* (kg) & $4.35 \pm 0.85$ & $3.88 \pm 0.25$ & $4.87 \pm 0.38$ & 0.43606 & 0.57284 \\
\hline Initial length* $(\mathrm{cm})$ & $54.53 \pm 0.52$ & $50.86 \pm 0.62$ & $57.64 \pm 3.05$ & 0.08215 & 0.23386 \\
\hline Final length* $(\mathrm{cm})$ & $9.85 \pm 4.70$ & $76.00 \pm 3.00$ & $81.35 \pm 0.80$ & 0.34242 & 0.29130 \\
\hline \multirow[t]{2}{*}{ SGR $(\%)$} & $1.05 \pm 0.18$ & $1.215 \pm 0.06$ & $1.00 \pm 0.13$ & 0.10040 & 0.05837 \\
\hline & \multicolumn{5}{|c|}{ Phase II - 130 to 287 days } \\
\hline Initial weight* (kg) & $4.35 \pm 0.85$ & $3.76 \pm 0.19$ & $4.99 \pm 0.29$ & 0.3038 & 0.52793 \\
\hline Final weight* (kg) & $8.80 \pm 1.69 a b$ & $8.01 \pm 1.46 \mathrm{~b}$ & $9.49 \pm 1.34 \mathrm{a}$ & 0.03099 & 0.004778 \\
\hline Initial length* $(\mathrm{cm})$ & $79.90 \pm 4.73$ & $75.15 \pm 2.56$ & $82.12 \pm 0.17$ & 0.1902 & 0.2368 \\
\hline Final length* $(\mathrm{cm})$ & $97.30 \pm 7.156$ & $95.20 \pm 8.22$ & $99.79 \pm 5.81$ & 0.120861 & 0.009565 \\
\hline \multirow[t]{2}{*}{ SGR (\%) } & $0.660 \pm 0.001$ & $0.605 \pm 0.12$ & $0.720 \pm 0.19$ & 0.58817 & 0.19936 \\
\hline & \multicolumn{5}{|c|}{ General - 0 to 287 days } \\
\hline Final biomass (kg) & $878.41 \pm 193.66$ & $727.52 \pm 382.43$ & $847.65 \pm 187.82$ & 0.49083 & 0.05762 \\
\hline Survival (\%) & $78.00 \pm 19.80$ & $72.40 \pm 7.40$ & $76.40 \pm 1.70$ & 0.8750 & 0.3064 \\
\hline Feed Conversion & $2.75 \pm 1.09$ & $2.82 \pm 0.64$ & $2.85 \pm 0.35$ & 0.9665 & 0.0855 \\
\hline $\mathrm{b}$ & 3.46 & 3.60 & 3.59 & 0.1712 & - \\
\hline
\end{tabular}
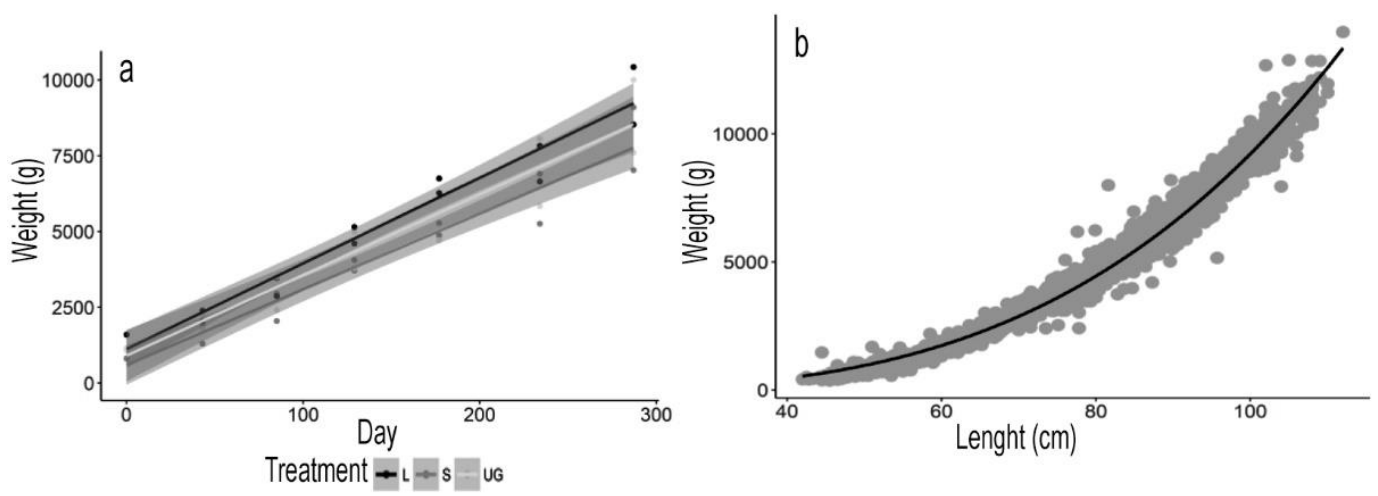

Figure 1. a) Weight gain, b) length-weight relationship of pirarucu Arapaima gigas reared in earthen ponds for 287 days and subjected to size grading.

flavescens (Wallat et al., 2005), despite resulting in different biomasses, size grading for pirarucu did not influence water quality parameters.

Although not statistically significant, there was a trend which suggested that L-graded fish presented higher final weight by the end of phase II than the Sgraded or ungraded fish groups, similar result reported for the North African catfish Clarias gariepinus (Burchell, 1822) (Martins et al., 2005) and paddlefish Polyodon spathula (Walbaum, 1792) (Onders et al., 2011) subjected to size grading. Considering that size grading aims at reducing social dominances and allow fish to better express their potential growth (Jobling \& Reinsnes, 1987; Johnson, 1997; Martins et al., 2005), it was expected that by the end of the culture phases, compensatory growth would be observed in the graded fish. Nevertheless, pooled S- and L-graded fish weight did not differ from the ungraded fish, which demonstrates that size grading did not favor general growth performance of pirarucu, the same as observed for Xiphophorus helleri Heckel, 1848 (Endemann et al., 1997), North African catfish (Martins et al., 2005) and 

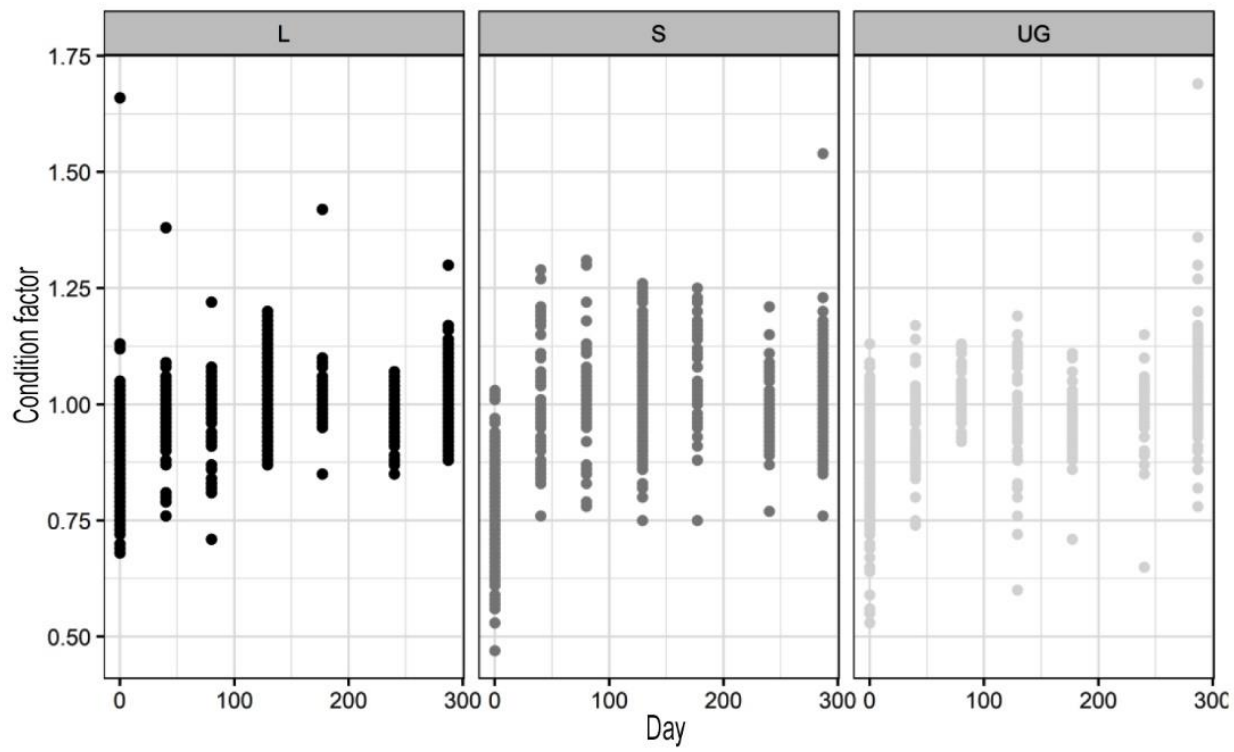

Figure 2. Condition factor of pirarucu Arapaima gigas reared in earthen ponds for 287 days and subjected to size grading. Small (S), large (L), and ungraded (UG) fish groups.
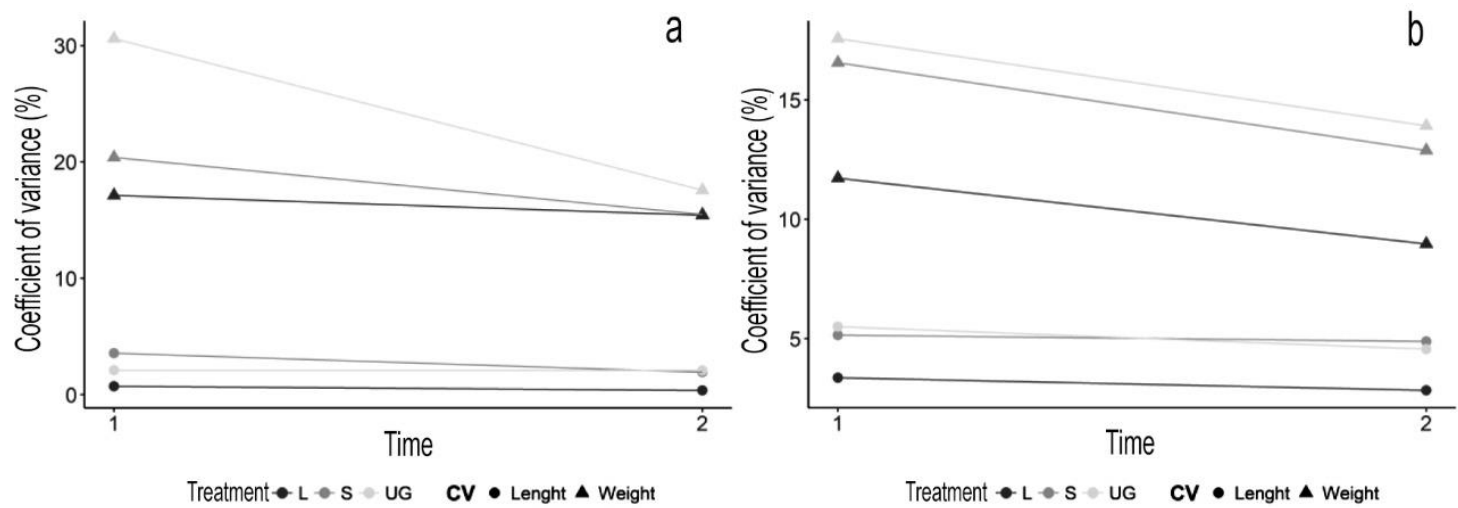

Figure 3. Heterogeneous weight gain and length of pirarucu Arapaima gigas reared in earthen ponds and subjected to size grading in two production phases: a) until 129 days, and b) from 130 to 287 days. The coefficient of variation (CV) is presented for weight and length. L, S, and UG represent fish groups graded as large, small and ungraded, respectively.

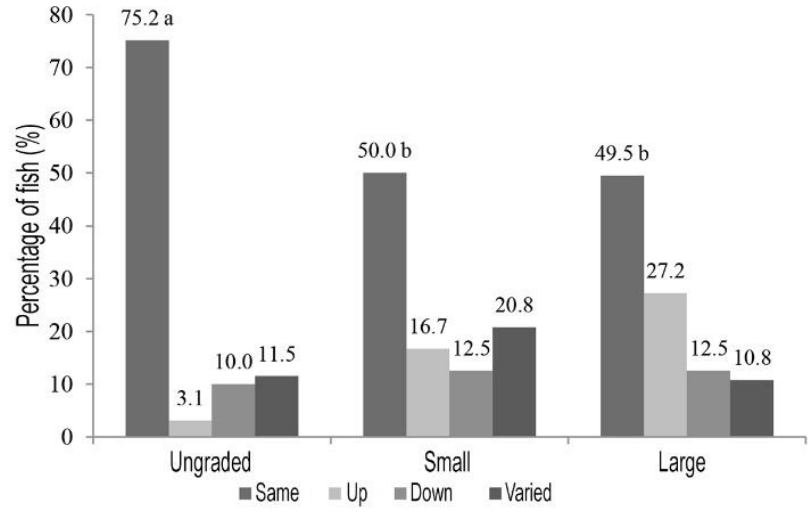

Figure 4. Change in hierarchical position (\%) of pirarucu Arapaima gigas reared in earthen ponds for 287 days and subjected to size grading. Means followed by different letters are significantly different (Tukey test, $P<0.05$ ).
Arctic charr Salvelinus alpinus (Linnaeus, 1758) (Wallace \& Kolbeinshavn, 1988). On the other hand, no losses in productive performance were observed, as reported for S. alpinus (Baardvik \& Jobling, 1990) and Atlantic halibut Hippoglossus hippoglossus (Linnaeus, 1758) (Stefansson et al., 2000). In this way, size grading during the pirarucu grow-out phase in earthen ponds did not improve production efficiency (Zakes et al., 2004), and it is not a practice indicated for the species and the production phases as assessed in conditions similar to commercial farming. Wallace \& Kolbeinshavn (1988) have remarked that most of the studies concluding that grading is a feasible management practice were done in a laboratory-scale with few animals. 
Table 2. Water quality parameters for pirarucu Arapaima gigas reared in earthen ponds for 287 days and subjected to size grading.

\begin{tabular}{lccccc}
\hline \multirow{2}{*}{ Parameter } & \multicolumn{3}{c}{ Size grading } & $\begin{array}{c}P \text {-value } \\
\text { (Treatment) }\end{array}$ & $\begin{array}{c}P \text {-value } \\
\text { (Block) }\end{array}$ \\
\cline { 2 - 5 } & Ungraded & S-graded & L-graded & 0.7367 & 0.0005 \\
Temperature $\left({ }^{\circ} \mathrm{C}\right)$ & $26.42 \pm 2.78$ & $26.33 \pm 2.98$ & $26.37 \pm 2.91$ & 0.8705 & 0.0334 \\
Transparency $(\mathrm{cm})$ & $65.58 \pm 35.52$ & $71.64 \pm 22.64$ & $69.08 \pm 44.86$ & 0.8705 & 0.3701 \\
Ammonia $\left(\mathrm{mg} \mathrm{NH}_{4} \mathrm{~L}^{-1}\right)$ & $0.15 \pm 0.09$ & $0.17 \pm 0.05$ & $0.09 \pm 0.02$ & 0.4858 & 0.0166 \\
Alkalinity $\left(\mathrm{mg} \mathrm{CacO}_{3} \mathrm{~L}^{-1}\right)$ & $18.57 \pm 10.71$ & $25.26 \pm 16.81$ & $24.38 \pm 15.73$ & 0.2863 & 0.0166 \\
$\mathrm{pH}$ & $7.18 \pm 0.78$ & $6.98 \pm 0.85$ & $7.38 \pm 1.59$ & 0.7223 & 0.0541 \\
Carbon dioxide $\left(\mathrm{mg} \mathrm{CO}_{2} \mathrm{~L}^{-1}\right)$ & $3.51 \pm 1.86$ & $4.32 \pm 1.11$ & $2.15 \pm 3.04$ & 0.2815 & 0.0702 \\
$\mathrm{O}_{2}\left(\mathrm{mg} \mathrm{O}_{2} \mathrm{~L}^{-1}\right)$ & $7.12 \pm 1.96$ & $6.45 \pm 1.33$ & $7.83 \pm 2.68$ & 0.3295 & 0.0367 \\
\hline
\end{tabular}

Although not statistically significant, the trend of higher growth rate and a high percentage of individuals increasing hierarchical position in the S-graded fish group suggest compensatory growth in the first rearing phase, favored by the absence of large fish (Barki et al., 2000). This behavior was not observed in the second phase, when L-graded fish presented a trend of a higher growth rate, indicating that the presence of large fish only suppressed growth in the initial phases. Nevertheless, Sunde et al. (1998) only observed a higher growth rate in S-graded Scophthalmus maximus (Linnaeus, 1758) towards the end of the study period, which was explained as size-specific growth. Reduction in SGR as they grow is a common behavior in fish (Jobling, 1985; Sunde et al., 1998; Sun \& Chen, 2014) and observed in the present study in all treatments, with significance only in the S-graded group. Pirarucu survival and feed conversion were not influenced by grading, corroborating to results reported for yellow perch (Wallat et al., 2005), turbot Scophthalmus maximus (Sunde et al., 1998) and North African catfish (Martins et al., 2005).

The weight-length relationship in pirarucu presented an exponential coefficient of 3.2656, which indicates a positive allometric growth for the species in the rearing conditions of the present study. Considering that the exponent may vary according to some factors, such as season, population and environmental conditions (Froese, 2006), pirarucu reared in earthen ponds present increased weight gain than length during the production cycle, as reported as a common characteristic for several fish species (Cifuentes et al., 2012).

High CV was observed in pirarucu weight at the beginning of the study, mainly in the ungraded fish group, corroborating data presented by Cavero et al. (2003b) for small pirarucu (approximately $100 \mathrm{~g}$ ) and by Gjerdrem (2005), who reported CV values for fish between 20 and 35\%, which are higher than values for most of the farmed animals (7 to 10\%). It is expected that heterogeneous fish size groups result in high variability by the end of the culture period (Smith \& Fuiman, 2003). However, for pirarucu, the CV values by the end of the production phases were similar between graded and ungraded fish, which has been reported for paddlefish reared in earthen ponds (Onders et al., 2011). According to Volpato \& Fernandes (1994), the increase in the CV may occur following size grading procedure, but it was not observed for pirarucu in the phases tested in the present study. Along the culture period, a trend of decrease in CV was observed, as reported for silver perch Bidyanus bidyanus (Barki et al., 2000) and yellow perch reared for 12 months (Wallat et al., 2005). Accordingly, the trend of pirarucu to reduce growth $\mathrm{CV}$ along the culture cycle was observed, typical behavior of gregarious fish species (Yamagashi, 1969), which supports the fact that grading pirarucu does not improve productivity.

As regards hierarchical position, within size graded fish, more individuals increased social status, as described by Martins et al. (2005) for the North African catfish. After grading, there might be more social interaction between individuals of the same size and stimulate new social hierarchical arrangements (Volpato \& Fernandes, 1994; Zakes et al., 2004). On the other hand, a highly heterogeneous fish (ungraded) group led the individuals to remain in the same hierarchical position, as the small fish are inhibited by the presence of larger conspecifics (Mgaya \& Mercer, 1995).

The growth potential in captivity is one of the main characteristics that attract investments from the productive sector to the production of pirarucu (FAO, 2012). Such potential has been observed in the present study, as fish final weight was of 8.0 to $9.5 \mathrm{~kg}$ in 287 days of culture, which are very high values compared to the main fish species farmed in Brazil, such as Nile tilapia Oreochromis niloticus (Linnaeus, 1758) and tambaqui Colossoma macropomum (Cuvier, 1816) (Lima et al., 2013). Additionally, the market value of pirarucu (US\$ $2.81 \mathrm{~kg}^{-1}$ ) is also higher than tilapia (US\$ $1.49 \mathrm{~kg}^{-1}$ and tambaqui (US\$ $1.72 \mathrm{~kg}^{-1}$ ) (IBGE, 2016). 
Pirarucu growth performance was even higher than reported by Pereira-Filho et al. (2003), who reared 133 $\mathrm{g}$ pirarucu in an earthen pond for 12 months to a final weight of $7.0 \mathrm{~kg}$. In this case, the stocking density that was three times higher in the study by Pereira-Filho et al. (2003) may have caused such difference.

Finally, the size grading of pirarucu did not improve growth performance, and it may be used to form groups of fish to reach the market size faster, as suggested by Wallat et al. (2005). However, it should be taken into account that, further to not improving fish growth, grading may increase production costs, increase diseases due to handling, reduce growth, and even loss of individuals (Sunde et al., 1998).

\section{CONCLUSION}

Size grading in pirarucu Arapaima gigas resulted in higher final weight in the L-graded fish group, followed by the ungraded and S-graded fish groups after 287 days of culture. Nevertheless, the pooled final weight of S- and L-graded fish did not differ from the ungraded fish group, which shows that size grading does not improve general performance in pirarucu. However, it may be used to form groups of fish to reach the commercial size faster or to produce a more uniform size fish if that is desired by the wholesalers/ processors/market.

\section{ACKNOWLEDGMENTS}

This work was supported by the Brazilian Ministry of Agriculture, Livestock and Supply through the National Council of Technological and Scientific Development (CNPq grant $\mathrm{N}^{\circ} 457465 / 2012-3$ ); and by the Brazilian Micro and Small Business Support Service (SEBRAE) through the Tocantins Research Foundation (FAPTO agreement 9/2012, grant no. 2538/2012). The authors are grateful to Serra Azul Farm and Baixão Verde Farm for providing farming facilities and to T.V. Costa for help in fish handling.

\section{REFERENCES}

Baardvik, B.M. \& Jobling, M. 1990. Effect of size-sorting on biomass gain and individual growth rates in Arctic charr, Salvelinus alpinus L. Aquaculture, 90: 11-16.

Bard, J. \& Imbiriba, E.P. 1986. A piscicultura do pirarucu, Arapaima gigas. Circular Técnica, Embrapa Amazônia Oriental, Belém, 17 pp.

Barki, A., Harpaz, S., Hulata, G. \& Karplus, I. 2000. Effects of larger fish and size grading on growth and size variation in fingerling silver perch. Aquaculture International, 8: 391-401.

Box, G.E.P. \& Cox, D.R. 1964. An analysis of transformation. Journal of the Royal Statistical Society, 26: 211-243.

Boyd, C.E. \& Lichtkoppler, F. 1979. Water quality management in pond fish culture. Research and Development Series 22. International Center for Aquaculture, Agricultural Experimental Station, University of Auburn, Alabama, 32 pp.

Cavero, B.A.S., Pereira-Filho, M., Roubach, R., Ituassú, D.R., Gandra, A.L. \& Crescêncio, R. 2003b. Efeito da densidade de estocagem na homogeneidade do crescimento de juvenis de pirarucu em ambiente confinado. Pesquisa Agropecuária Brasileira, 38: 103107.

Cavero, B.A.S., Ituassú, D.R., Pereira-Filho, M., Roubach, R., Bordinhon, A.M., Leão Da Fonseca, F.A. \& Ono, E.A. 2003a. Uso de alimento vivo como dieta inicial no treinamento alimentar de juvenis de pirarucu. Pesquisa Agropecuária Brasileira, 38: 10111015.

Cavero, B.A.S., Pereira-Filho, M., Bordinhon, A.M., Da Fonseca, F.A.L., Ituassú, D.R., Roubach, R. \& Ono, E.A. 2004. Tolerância de juvenis de pirarucu ao aumento da concentraç ão de amônia em ambiente confinado. Pesquisa Agropecuária Brasileira, 39: 513516.

Cifuentes, R., González, J., Montoya, G., Jara, A., Ortíz, N., Piedra, P. \& Habit, E. 2012. Relación longitudpeso y factor de condición de los peces nativos del río San Pedro (cuenca del río Valdivia, Chile). Gayana, 76: 86-100.

Cutts, C.J., Metcalfe, N.B. \& Taylor, A.C. 1998. Aggression and growth depression in juvenile Atlantic salmon: the consequences of individual variation in standard metabolic rate. Journal of Fish Biology, 52: 1026-1037.

Endemann, F., Kaiser, H. \& Hecht, T. 1997. Size-sorted juvenile swordtails, Xiphophorus helleri Heckel 1848 (Family Poeciliidae), do not show improved growth. Aquaculture Research, 28: 645-647.

Fogaça, F.H.D.S., De Oliveira, E.G., Carvalho, S.E.Q. \& Santos, J.F.D.S. 2011. Yield and composition of pirarucu fillet in different weight classes. Acta Scientiarum. Animal Sciences, 33: 95-99.

Food and Agriculture Organisation of the United Nations (FAO). 2012. Arapaima gigas (Schinz, 1822). Cultured aquatic species information programme. Fisheries and Aquaculture Department, FAO. [http://www. fao.org/fishery/culturedspecies/Arapaima_gigas/en]. Reviewed: February 7, 2019.

Froese, R. 2006. Cube law, condition factor and weightlength relationships: history, meta-analysis and 
recommendations. Journal of Applied Ichthyology, 22: 241-253.

Gjedrem, T. 2005. Selection and breeding programs in aquaculture. Springer, New York.

Instituto Brasileiro do Meio Ambiente e dos Recursos Naturais Renováveis (IBAMA). 2005. Estatística da Pesca 2004. Ministério do Meio Ambiente. [http:// www.icmbio.gov.br/cepsul/images/stories/ biblioteca /download/estatistica/est_2005_boletim_04_brasil.pd f]. Reviewed: February 10, 2019.

Instituto Brasileiro de Geografia e Estatística (IBGE). 2016. Produção da pecuária municipal 2015. Volume 43. Ministério do Planejamento, Desenvolvimento e Gestão, IBGE, Rio de Janeiro. [https://biblioteca.ibge. gov.br/visualizacao/periodicos/84/ppm_2015_v43_br. pdf]. Reviewed: February 10, 2019.

Imbiriba, E.P. 2001. Potencial de criação de pirarucu, Arapaima gigas, em cativeiro. Acta Amazonica, 2: 299-316.

Jensen, G.L. 1990. Sorting and grading warmwater fish. Southern Regional Aquaculture Center, 391, Mississippi. [https://www.ncrac.org/files/biblio/SR AC0391.pdf]. Reviewed: December 17, 2019.

Jobling, M. 1985. Physiological and social constraints on growth of fish with special reference to Arctic Charr, Salvelinus alpinus L. Aquaculture, 44: 83-90.

Jobling, M. \& Reinsnes, T.G. 1987. Effect of sorting on size-frequency distributions and growth of Arctic charr, Salvelinus alpinus L. Aquaculture, 60: 27-31.

Johnsson, J.I. 1997. Individual recognition affects aggression and dominance relations in rainbow trout, Oncorhynchus mykiss. Ethology, 103: 267-282.

Koebele, B.P. 1985. Growth and the size hierarchy effect: an experimental assessment of three proposed mechanisms; activity differences, disproportional food acquisition, physiological stress. Environmental Biology of Fishes, 12: 181-188.

Le Cren, E.D. 1951. The length-weight relationship and seasonal cycle in gonad weight and conditions in the perch (Perca fluviatilis). Journal of Animal Ecology, 20: 201-219.

Lima, A.F., Bergamin, G.T. \& Moro, G.V. 2013. Engorda de peixes. In: Rodrigues, A.P.O., Lima, A.F., Alves, A.L., Rosa, D.K., Torati, L.S. \& Dos Santos, V.R.V. (Eds.). Piscicultura de água doce: multiplicando conhecimentos. Embrapa, Brasília, pp. 347-377.

Lima, A.F., Silva, A.P., Rodrigues, A.P.O., Sousa, D.N., Bergamin, G.T., Lima, L.K.F., Torati, L.S., PedrozaFilho, M.X., Maciel, P.O. \& Flores, R.M.V. 2015. Manual de piscicultura familiar em viveiros escavados, Embrapa, Brasília, 143 pp.

Martins, C.I.M., Aanyu, M., Schrama, J.W. \& Verreth, J.A.J. 2005. Size distribution in African catfish
(Clarias gariepinus) affects feeding behaviour but not growth. Aquaculture, 250: 300-307.

Mgaya, Y.D. \& Mercer, J.P. 1995. The effects of size grading and stocking density on growth performance of juvenile abalone, Haliotis tuberculata Linnaeus. Aquaculture, 136: 297-312.

Onders, R.J., Mims, S.D. \& Dasgupta, S. 2011. Effect of size-grading and feeding frequency on growth and size variation of paddlefish, Polyodon spathula, juveniles reared in ponds. Journal of the World Aquaculture Society, 42: 127-134.

Ono, E. \& Kedhi, J. 2013. Manual de boas práticas de produção do pirarucu em cativeiro. Serviço Brasileiro de Apoio às Micros e Pequenas Empresas, Brasília, 76 pp.

Pereira-Filho, M., Cavero, B.A.S., Roubach, R., Ituassú, D.R., Gandra, A.L. \& Crescêncio, R. 2003. Cultivo do pirarucu (Arapaima gigas) em viveiro escavado. Acta Amazonica, 33: 5-8.

R Core Team. 2016. R: a language and environment for statistical computing. R Foundation for Statistical Computing, Vienna. [https://www.r-project.org/]. Reviewed: February 15, 2019.

Rebelatto-Junior, I.A., Lima, A.F., Rodrigues, A.P.O., Maciel, P.O., Kato, H.C.A., Mataveli, M., Rezende, F.P., Varela, E.S., Sousa, A.R.B., Santos, C., Boijink, C.L., Yoshioka, E.T.O. \& O'Sullivan, F.L.A.. 2015. Reprodução e engorda do pirarucu: levantamento de processos produtivos e tecnologias, Embrapa, Brasília, 108 pp. [http://ainfo.cnptia.embrapa.br/digital/bitstream/item/144252/1/CNPASA-2015-lv.pdf]. Reviewed: February 20, 2019.

Saint-Paul, U. 1986. Potential for aquaculture of South American freshwater fishes: a review. Aquaculture, 54: 205-240.

Stefansson, M.O., Imsland, A.K., Jenssen, M.D., Jonassen, T.M., Stefansson, S.O. \& FitzGerald, R. 2000. The effect of different initial size distributions on the growth of Atlantic halibut. Journal of Fish Biology, 56: 826-836.

Sun, L. \& Chen, H. 2014. Effects of water temperature and fish size on growth and bioenergetics of cobia (Rachycentron canadum). Aquaculture, 426-427: 172180.

Sunde, L.M., Imsland, A.K., Folkvord, A. \& Stefansson, S.O. 1998. Effects of size grading on growth and survival of juvenile turbot at two temperatures. Aquaculture International, 6: 19-32.

Szczepkowski, M., Zakeś, Z., Szczepkowska, B. \& Piotrowska, I. 2011. Effect of size sorting on the survival, growth and cannibalism in pikeperch (Sander lucioperca L.) larvae during intensive culture in RAS. Czech Journal of Animal Science, 56: 483-489. 
Smith, M.E. \& Fuiman, L.A. 2003. Causes of growth depensation in red drum, Sciaenops ocellatus, larvae. Environmental Biology of Fishes, 66: 49-60.

Volpato, G.L. \& Fernandes, M.O. 1994. Social control of growth in fish. Brazilian Journal of Medical and Biological Research, 27: 797-810.

Wallace, J.C. \& Kolbeinshavn, A.G. 1988. The effect of size grading on subsequent growth in fingerling Arctic charr, Salvelinus alpinus (L.). Aquaculture, 73: 97100 .

Received: 15 April 2019; Accepted: 10 July 2019
Wallat, G.K., Tiu, L.G., Wang, H.P., Rapp, D. \& Leighfield, C. 2005. The effects of size grading on production efficiency and growth performance of yellow perch in earthen ponds. North American Journal of Aquaculture, 67: 34-41.

Yamagishi, H. 1969. Postembryonal growth and its variability of the three marine fishes with special reference to the mechanism of growth variation in fishes. Researches on Population Ecology, 11: 14-33.

Zakes, Z., Kowalska, A. \& Czerniak, S. 2004. Effect of sorting on selected rearing factors of pikeperch Sander lucioperca (L.). Archives of Polish Fisheries, 12: 7179. 